\title{
Assessment of Sewage Water Treatment Using Grinded Bauxite Rock as a Robust and Low-Cost Adsorption
}

\author{
Mutairah Shaker Alshammari iD \\ Chemistry Department, College of Science, Jouf University, P.O. Box: 2014, Sakaka, Saudi Arabia \\ Correspondence should be addressed to Mutairah Shaker Alshammari; msshamari@ju.edu.sa
}

Received 19 December 2019; Revised 12 January 2020; Accepted 22 January 2020; Published 27 February 2020

Guest Editor: Mohammad Saad Algamdi

Copyright (C) 2020 Mutairah Shaker Alshammari. This is an open access article distributed under the Creative Commons Attribution License, which permits unrestricted use, distribution, and reproduction in any medium, provided the original work is properly cited.

\begin{abstract}
The shortage of water resources in Saudi Arabia is becoming an increasingly serious problem. Management of sewage water is an attractive option to reduce the contamination of water resources such as ground water. This work aims to use bauxite rock as a low-cost adsorbent/coagulant for sewage water treatment in a simple and rapid technique. Different doses $(1,2,3,4$ and $5 \mathrm{~g} / \mathrm{l})$ of the grinded bauxite was used as an adsorbent/coagulant. The results revealed that, at rock doses of 1, 2, 3, 4, and $5 \mathrm{~g} / \mathrm{l}$, the COD concentration was decreased from 326 to $134,98,83,70$, and $65 \mathrm{mg} / \mathrm{l}$, respectively, while the BOD concentration was lowered from 243 to $196,104,71,60,51$, and 47 for the same rock doses. This was reflected on the turbidity of the treated effluent from each treatment step. Also, the FC counts were reduced to $2 \mathrm{log}$ units. Furthermore, the dose of $3 \mathrm{~g} / \mathrm{l}$ of the grinded bauxite rock was found to be the least economic dose for the treatment of sewage water. Bauxite mineral has been used explicitly in a highperformance, very affordable method for wastewater treatment.
\end{abstract}

\section{Introduction}

As the population of the world grows and water resource problems keep making headlines, it has never been more essential to preserve water supplies to our maximum extent capacity and to make sure that the water at our disposal is clean and free from pollutants. Organic loads, nutrients, and pathogens contribute major threats in water resources. The removal of such contaminants in wastewater is one of the fundamental aims in waste management. A range of techniques were used for the treatment of various types of wastes to suitable standards $[1,2]$. However, conventional waste treatment technologies are expensive. Consequently, several research efforts are running to develop low-cost treatment technologies appropriate in developing countries [2]. Furthermore, during the last few decades, stringent regulation of waste discharge into the environment is receiving wider attentions. To comply with these standards and preserve safe environment, it has become necessary to find some cost-effective treatment techniques. In order to achieve cost-effective technologies, natural materials such as rocks and sands are widely applied in wastewater treatment for removing pollutants [3]. Several methods were established to remove hazardous substances from wastewater such as precipitation, reverse osmosis, ion exchange, and adsorption $[4,5]$.

Among all past strategies, adsorption using clay and other composite materials is regarded to be a particularly effective technique, mainly by using minimal-cost and economical methods to eliminate contaminants from industrialized wastewater and aqueous solutions [6-8].

Natural clay minerals and activated carbon with large removal capability are the most popular sorption approaches $[9,10]$. Several studies centered on the use of low-cost, extremely efficient pollutant sorbents and also examined the sorption activities of several recycled materials and chemicals [11]. Most of these are clay composites [12], agricultural products, certain aquatic plants, and micro-organisms [11]. Many of these studies have already shown that natural materials are capable of acting as good adsorbents for hazardous contaminants like heavy metals $[13,14]$, while the kinds and quality of clay materials are also essential as they 
are included in selecting which contaminants to address. Ali et al. [15] conducted the adsorption of harmful pollutants from wastewater applying natural zeolite. The results suggest that clinoptilolite removal for ammonium varied from 70 to 92 percent, whilst at different circumstances, it varied from 70 to 99 percent for heavy metals. Bhattacharya et al. [16] examined the adsorption performance of zinc from an aquatic environment with different adsorbents; the results obtained revealed that the percentage of zinc removal rised by raising the adsorbent dosage to achieve full adsorption at 98 percent and $\mathrm{pH}$ around 5 and 7 [17]. The adsorption of $\mathrm{Cd}^{+2}$ on the surface of nanomaterial based on wollastonite prepared with/without $\mathrm{CuO}$ was examined. The results showed that at optimum operating conditions (at $\mathrm{pH} 9$ ), cadmium ions removal reached $98.88 \%$.

Combined with the growing need for superior quality of water, a growing research for the use of low-cost materials as an adsorbent for water treatment will be an initiative that would be a serious environmental success. Therefore, the main aim of this study is intended to examine and evaluate the ability of certain metal ions to removal using bauxite rocks as natural and low-cost material for the treatment of water and sewage water in Saudi Arabia. The removal experiments were conducted and optomized in the laboratory using the original concentration of metal ions, solution $\mathrm{pH}$, and contact time as variables.

\section{Materials and Methods}

2.1. Rock Samples. In the northeastern part of the city of Hail, 200 kilometers from the province of Baqa'a lies the village of Zubayra rich in bauxite ore, which is the basic raw material for the production of aluminum, where it is available in large quantities. Bauxite was collected from Zubayra city [18]. The rock was initially grinded to $0.5-1 \mathrm{~mm}$ particle diameter and dried. Scanning Electron Microscope (SEM) Model Quanta 250 FEG (Field Emission Gun) attached with EDX Unit (Energy Dispersive X-ray Analyses), with accelerating voltage $30 \mathrm{~K} \cdot \mathrm{V}$., magnification $14 \mathrm{x}$ up to 1000000 and resolution for Gun.1n) has been performed.

2.2. Sewage Water Samples. Sewage water samples were brought from Sakaka wastewater treatment plant. Within 2 hours after collection, sewage water samples were analyzed [19].

2.3. Method of Jar Test. Jar testing is a process of observing a full-scale method of water purification, offering a sensible idea of how a chemical treatment will operate and perform with a specific type of raw water. Because it imitates full-scale service, process technicians could use jar analysis to identify which chemical treatment looks best with the raw water of their system. Sewage water samples were subjected to a jar test for application of grinded rock adsorption. Different doses of rock $(1,2,3,4$, and $5 \mathrm{~g} / \mathrm{l})$ were tested for the treatment of sewage water. The flash mixing speed was $250 \mathrm{rpm}$ for 1 minute followed by flocculation at $100 \mathrm{rpm}$ for 30 minutes. The flocculation speed was chosen as $100 \mathrm{rpm}$ due to the precipitation of the grinded rocks and to be in contact with the sewage samples. The test was carried out in 1 liter beakers. The same procedures were carried out in a blank (sample without addition of grinded rock) [19].

2.4. Analysis. During the time of study, the efficiency of the treatment procedure was studied. For samples (raw and treated sewage water), physicochemical and biological analyzes were performed. PH, total suspended solids (TSS), chemical oxygen demand (COD), biological oxygen demand (BOD), and fecal coliform were included in the physicochemical analyzes. The analyses were performed in accordance with the American Public Health Association, Standard Water, and Wastewater Analysis Methods [19].

\section{Results and Discussion}

3.1. Material Characterization. The main composition of the ore is presented in Table 1. Based on multipoint EDX assessment, there are obviously noticeable round hematite particles with other elements in these regions that is supposed to be given a high bauxite content of $\mathrm{Fe}_{2} \mathrm{O}_{3}$. The findings of these analyses that are provided are another evidence of the complicated structure of bauxite and support the data found in the literature suggesting that bauxite minerals are interconnected rather than separately occurring.

3.2. Sewage Water Characteristics. From the results depicted in Table 2 and Figure 1, it is clear that the sewage water used in this study is classified as a low-strength wastewater [20]. The average values for COD, BOD, and TSS were 326, 242.3, and $123.5 \mathrm{mg} / \mathrm{l}$, respectively. The $\mathrm{BOD} / \mathrm{COD}$ ratio shows the biodegradability of the used wastewater.

3.3. Efficiency of the Treatment Process. In an attempt to enhance the sedimentation of sewage water, the grinded bauxite rock was used. Figure 2 shows the variation of EC, TDS, and turbidity along with the different doses of rock. The levels of TDS and EC were inversely proportional with the turbidity of the raw sewage as well as the samples.

Figure 3 shows the depletion of the concentration of COD with various doses of the rock. It is clear that the concentration of COD reduced by increasing the dose of the rock. The concentration of COD was reduced from 326 to $134,98,83,70$, and $65 \mathrm{mg} / \mathrm{l}$ at rock doses of $1,2,3,4$, and $5 \mathrm{~g} / \mathrm{l}$, respectively. The same pattern was noted for both BOD and TSS reduction.

Figure 4 shows the performance of the treatment of sewage water with bauxite rocks. By applying bauxite as an adsorbent, the FC amount was decreased by two logs. The FC count was reduced from $5.5 \times 10^{7}$ to $4.2 \times 10^{5}, 3.4 \times 10^{5}$, $2.8 \times 10^{5}, 2.4 \times 10^{5}$, and $2 \times 10^{5} \mathrm{MPN} / 100 \mathrm{ml}$ for raw sewage, $1,2,3,4$ and $5 \mathrm{~g} / \mathrm{l}$ rock, respectively. Table 3 summarizes the performance of bauxite rock for the treatment of sewage water. 
TABLE 1: The bauxite rock's main chemical composition.

\begin{tabular}{lcc}
\hline Element & Weight (\%) & Atomic (\%) \\
\hline $\mathrm{O}$ & 30.52 & 49.61 \\
$\mathrm{Al}$ & 34.51 & 33.27 \\
$\mathrm{Si}$ & 1.69 & 1.56 \\
$\mathrm{Ca}$ & 0.27 & 0.17 \\
$\mathrm{Fe}$ & 33.02 & 15.38 \\
\hline
\end{tabular}

TABle 2: Physicochemical features of the wastewater*.

\begin{tabular}{lcccc}
\hline Parameter & Unit & Minimum & Maximum & Average \\
\hline pH & - & 7.3 & 8.0 & 676.0 \\
EC & $\mathrm{mS}$ & 485.1 & 121 & 576.4 \\
Turbidity & $\mathrm{NTU}$ & 95 & 406 & 111.0 \\
TDS & $\mathrm{mg} / \mathrm{l}$ & 325 & 370.0 & 66.4 \\
COD & $\mathrm{mg} / \mathrm{l}$ & 274.0 & 275 & 326.0 \\
BOD & $\mathrm{mg} / \mathrm{l}$ & 205 & 0.75 & 243.3 \\
BOD/COD & & 0.74 & 135 & 0.745 \\
TSS & $\mathrm{mg} / \mathrm{l}$ & 110 & $7.0 \times 10^{7}$ & 123.5 \\
FC & MPN/100 ml & $3.3 \times 10^{7}$ & & $5.5 \times 10^{7}$ \\
\hline
\end{tabular}

${ }^{*}$ number of samples $=13$.

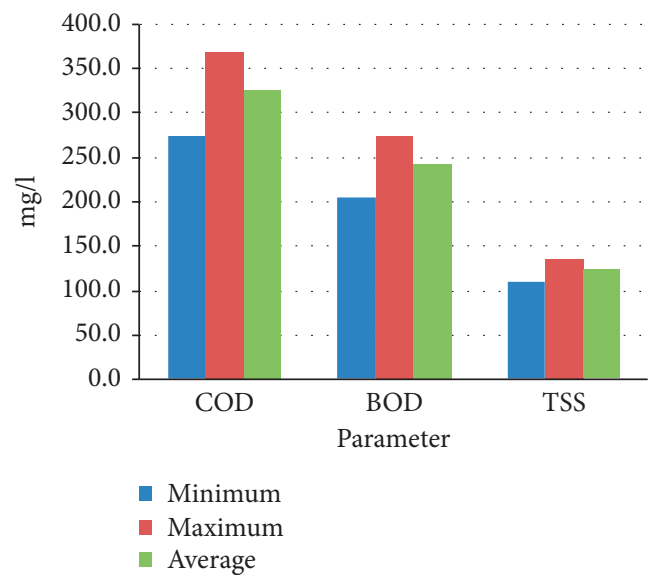

Figure 1: Characteristic of raw sewage water COD, BOD, and TSS.

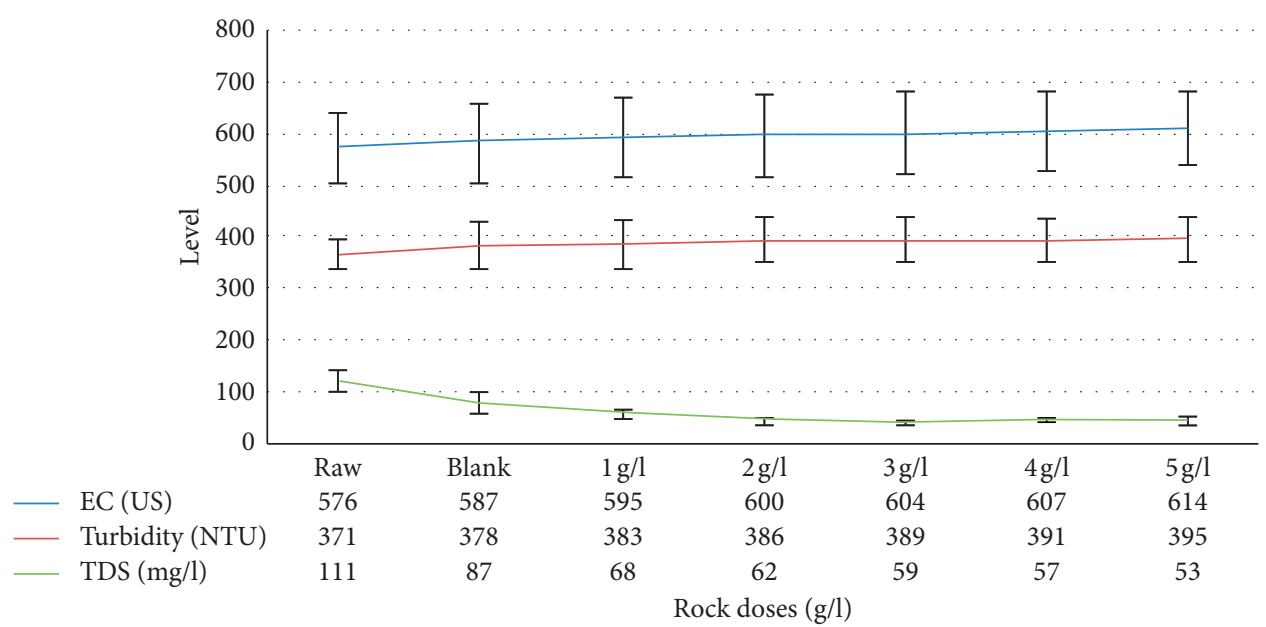

Figure 2: Variation of the levels of EC, Turbidity, and TDS along the treatment steps. 


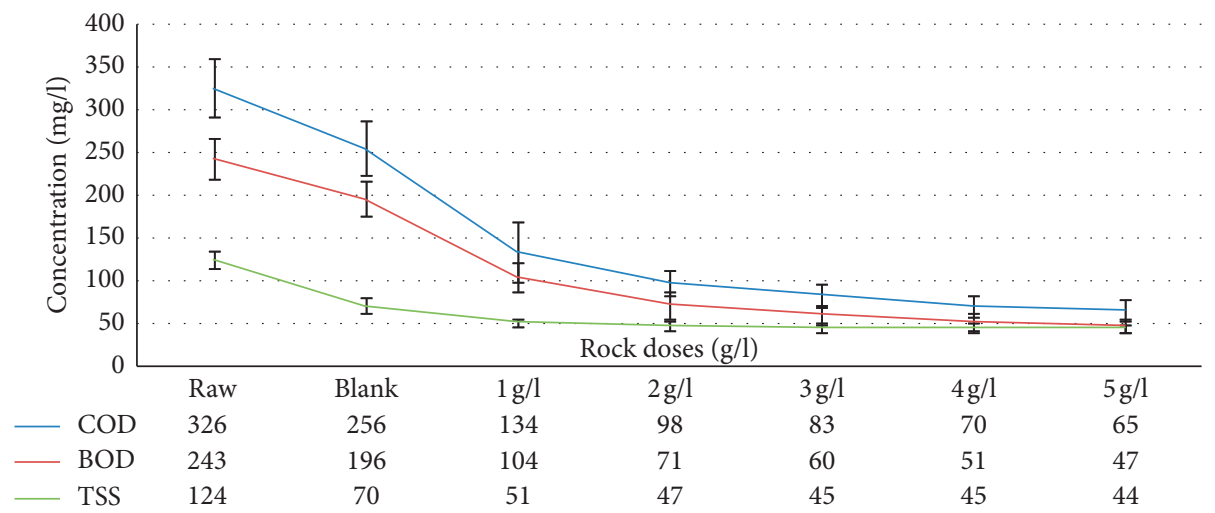

Figure 3: Depletion of the COD concentration with the rock dose.

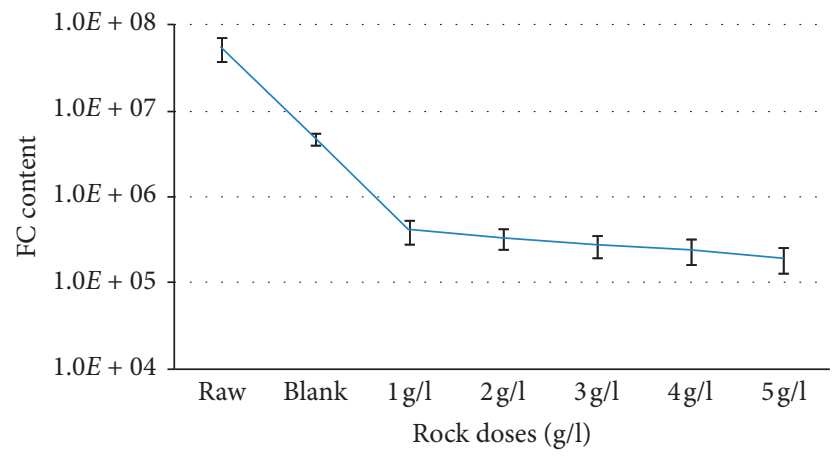

Figure 4: Variation of the FC count along with the treatment steps.

TABLE 3: Complete analysis of the raw waste water and different treated effluents.

\begin{tabular}{|c|c|c|c|c|c|c|c|c|c|c|c|c|c|}
\hline Parameter & Raw & Blank & $\% \mathrm{R}$ & $1 \mathrm{~g} / \mathrm{l}$ & $\begin{array}{c}\% \mathrm{R} \\
1 \mathrm{~g} / \mathrm{l}\end{array}$ & $2 \mathrm{~g} / \mathrm{l}$ & $\begin{array}{c}\% \mathrm{R} \\
2 \mathrm{~g} / \mathrm{l}\end{array}$ & $3 \mathrm{~g} / \mathrm{l}$ & $\begin{array}{c}\% \mathrm{R} \\
3 \mathrm{~g} / \mathrm{l}\end{array}$ & $4 \mathrm{~g} / \mathrm{l}$ & $\begin{array}{c}\% \mathrm{R} \\
4 \mathrm{~g} / \mathrm{l}\end{array}$ & $5 \mathrm{~g} / 1$ & $\%$ R $5 \mathrm{~g} / 1$ \\
\hline $\mathrm{pH}$ & 7.5 & 7.9 & & 8.0 & & 8.0 & & 7.8 & & 7.7 & & 7.5 & \\
\hline $\mathrm{EC}(\mu S)$ & 576 & 587 & & 595 & & 600 & & 604 & & 607 & & 614 & \\
\hline TDS (mg/l) & 371 & 378 & & 383 & & 386 & & 389 & & 391 & & 395 & \\
\hline $\begin{array}{l}\text { Turbidity } \\
\text { (NTU) }\end{array}$ & 111 & 87 & 22 & 68 & 21 & 62 & 28 & 59 & 32 & 57 & 34 & 53 & 39 \\
\hline COD & 326 & 256 & 22 & 134 & 48 & 98 & 61 & 83 & 67 & 70 & 72 & 65 & 75 \\
\hline BOD & 243 & 196 & 20 & 104 & 47 & 71 & 63 & 60 & 69 & 51 & 74 & 47 & 76 \\
\hline $\mathrm{BOD} / \mathrm{COD}$ & 0.75 & 0.74 & & 0.72 & 0.73 & & & 0.72 & & 0.72 & & 0.72 & \\
\hline TSS & 124 & 70 & 43 & 51 & 28 & 47 & 33 & 45 & 36 & 45 & 36 & 44 & 38 \\
\hline FC & $5.5 \times 10^{7}$ & $4.9 \times 10^{6}$ & 90.26 & $4.2 \times 10^{5}$ & 91.30 & $3.4 \times 10^{5}$ & 93.00 & $2.8 \times 10^{5}$ & 94.33 & $2.4 \times 10^{5}$ & 94.99 & $2.0 \times 10^{5}$ & 95.99 \\
\hline
\end{tabular}

3.4. Removal Mechanisms. There were two main mechanisms for removal of the organic loads from sewage water. The first was adsorption on the surface of the rock particles. The second was the coagulation that occurred due to the presence of $\mathrm{Al}$ and $\mathrm{Fe}$ in the rock composition. By increasing the rock dose, the surface area increased as well as the dissolution of some component of the rock. This was the reason for increasing the removal efficiency of the organic loads reflected by COD, BOD and TSS and in the consequence, increased the TDS of the treated samples. Raising the dose of rock has also enhanced the turbidity of the treated samples. It was observed that the adsorption capacity was not significantly raised by raising the rock dose from 3 to $5 \mathrm{~g} / \mathrm{l}$. The FC count also decreased by using the grinded rock as the coagulant. The main mechanism for removal of FC bacteria was the adsorption on the surface of the rock. Since it has a positively charged surface (due the presence of Fe and $\mathrm{Al}$ ), the FC bacteria had negatively charged functional groups. Grehs et al., [21] examined the removal of microorganisms by using aluminiumsulphate. They noticed that, as well as the bacterial numbers, turbidity and color were decreased by 1-2 logs. The removal of solid materials from water coagulation and flocculation methods are of major importance. Such methods could minimize color strength 
and decrease turbidity levels, organic compounds [22]. Aboubaraka et al. [23] examined graphene oxide for the elimination of turbidity from water, and his results were found to be higher than those obtained in this study.

\section{Conclusions}

The Bauxite can be crushed to a certain particle size to create a material with high performance in decreasing the water pollution as indicated by COD and BOD values. The findings showed that the COD concentration reduced from 326 to $134,98,83,70$, and $65 \mathrm{mg} / \mathrm{l}$ while the BOD concentration decreased from 243 to $196,104,71,60,51$, and 47 at rock doses of $1,2,3,4$, and $5 \mathrm{~g} / \mathrm{l}$ for both parameters. In addition, the use of such approach is known to be a rapid strategy of treating sewage water in different areas to reduce the potential for drinking water supplies (such as groundwater).

\section{Data Availability}

The data (including the results and all the values of the physicochemical analysis of water before and after treatment) used to support the findings of this study are included within the article. The data are represented in Figures and Tables.

\section{Conflicts of Interest}

The authors declare that they have no conflicts of interest.

\section{Acknowledgments}

The author is grateful to the Chemistry Department at Jouf University Sakaka, KSA, for support and giving the access for analysis.

\section{References}

[1] M. A. El-Khateeb and F. A. El-Gohary, "Combining UASB technology and constructed wetland for domestic wastewater reclamation and reuse," Water Science and Technology: Water Supply, vol. 3, no. 4, pp. 201-208, 2003.

[2] M. A. El-Khateeb, W. M. Emam, and W. A. Mohamed, "Essam Saber, integration of UASB and downflow hanging non-woven fabric (DHNW) reactors for the treatment of sewage water," Desalination and Water Treatment, vol. 164, no. 48-55, 2019.

[3] S. Ahsan, S. Kaneco, K. Ohta, T. Mizuno, and K. Kani, "Use of some natural and waste materials for waste water treatment," Water Research, vol. 35, no. 15, pp. 3738-3742, 2001.

[4] W. Y. Shi, H. B. Shao, H. Li, M. A. Shao, and S. Du, "Progress in the remediation of hazardous heavy metal-polluted soils by natural zeolite," Journal of Hazardous Materials, vol. 170, no. 1, pp. 1-6, 2009.

[5] A. E. A. Nayl, R. A. Elkhashab, T. El Malah et al., "Adsorption studies on the removal of COD and BOD from treated sewage using activated carbon prepared from date palm waste," Environmental Science and Pollution Research, vol. 24, no. 28, pp. 22284-22293, 2017.

[6] S. Lin and R. S. Juang, "Heavy metal removal from water by sorption using surfactant-modified montmorillonite," Journal of Hazardous Materials, vol. 92, no. 3, pp. 315-326, 2002.

[7] K. Swayampakula, V. M. Boddu, S. K. Nadavala, and K. Abburi, "Competitive adsorption of $\mathrm{Cu}$ (II), Co (II) and $\mathrm{Ni}$
(II) from their binary and tertiary aqueous solutions using chitosan-coated perlite beads as biosorbent," Journal of Hazardous Materials, vol. 170, no. 2-3, pp. 680-689, 2009.

[8] L. Wang, G. Hu, F. Lyu et al., "Application of red mud in wastewater treatment," Minerals, vol. 9, no. 5, p. 281, 2019.

[9] J. Ayala, J. L. Vega, R. Alvarez, and J. Loredo, "Retention of heavy metal ions in bentonites from Grau region (Northern Peru)," Environmental Geology, vol. 53, no. 6, pp. 1323-1330, 2008.

[10] S. S. Prajapati, P. A. Mohamed Najar, and V. M. Tangde, "Removal of phosphate using red mud: an environmentally hazardous waste by-product of alumina industry," Advances in Physical Chemistry, vol. 2016, Article ID 9075206, 9 pages, 2016.

[11] C. O. Ijagbemi, M.-H. Baek, and D.-S. Kim, "Montmorillonite surface properties and sorption characteristics for heavy metal removal from aqueous solutions," Journal of Hazardous Materials, vol. 166, no. 1, pp. 538-546, 2009.

[12] M. Solener, S. Tunali, A. S. Ozcan, A. Ozcan, and T. Gedikbey, "Adsorption characteristics of lead(II) ions onto theclay/pol$\mathrm{y}$ (methoxyethyl)acrylamide (PMEA) composite from aqueous solutions," Desalination, vol. 223, no. 1, pp. 308-322, 2008.

[13] M. M. Ali and E. E. El-Sayed, "Capability of natural bentonite for removing organic and inorganic pollutants from wastewater," Journal of Water Research-Photon Foundation, vol. 138, pp. 361-370, 2017.

[14] P. B. Cusack, O. Callery, R. Courtney, É. Ujaczki, L. M. T. O'Donoghue, and M. G. Healy, "The use of rapid, small-scale column tests to determine the efficiency of bauxite residue as a low-cost adsorbent in the removal of dissolved reactive phosphorus from agricultural waters," Journal of Environmental Management, vol. 241, pp. 273-283, 2019.

[15] M. M. Ali, E. E. El-Sayed, and M. Z. Kamel, "Removal of hazardous contaminants from wastewater using natural zeolite," Journal of Water Research-Photon Foundation, vol. 138, pp. 333-347, 2017.

[16] A. K. Bhattacharya, S. N. Mandal, and S. K. Das, "Adsorption of Zn(II) from aqueous solution by using different adsorbents," Chemical Engineering Journal, vol. 123, no. 1-2, pp. 43-51, 2006.

[17] N. Ammar, A. Ahmed Fahmy, K. S. H. Youssef, E. M. A. Hamzawy, and M. A. El-Khateeb, "Wollastonite ceramic/CuO nano-composite for cadmium ions removal from waste water," Egyptian Journal of Chemistry, vol. 60, no. 5, pp. 817-823, 2017.

[18] N. M. Khalil, Y. Algamal, and Q. M. Saleem, "Exploitation of petroleum waste sludge with local bauxite raw material for producing high-quality refractory ceramics," Ceramics International, vol. 44, no. 15, pp. 18516-18527, 2018.

[19] American Public Health Association (APHA), Standard Methods for the Examination of Water and Wastewater, APHA, Washington, DC, USA, 22nd edition, 2012.

[20] Metcalf and Eddy, Wastewater Engineering Treatment, Disposaland Reuse, McGraw-Hill, New York, NY, USA, 4th edition, 2005.

[21] B. W. N. Grehs, A. R. Lopes, N. F. F. Moreira et al., "Removal of microorganisms and antibiotic resistance genes from treated urban wastewater: a comparison between aluminium sulphate and tannin coagulants," Water Research, vol. 166, p. 115056, 2019.

[22] G. Zhu, H. Zheng, W. Chen, W. Fan, P. Zhang, and T. Tshukudu, "Preparation of acomposite coagulant: polymeric aluminum ferric sulfate (PAFS) for wastewatertreatment," Desalination, vol. 285, pp. 315e-323e, 2012.

[23] A. E. Aboubaraka, E. F. Aboelfetoh, and El-Z. M. Ebeid, "Coagulation effectiveness of graphene oxide for the removal ofturbidity from raw surface water," Chemosphere, vol. 181, pp. 738e-746e, 2017. 